\title{
PENGARUH PREMI ASURANSI DAN KUALITAS PELAYANAN TERHADAP KEPUASAN NASABAH PENGGUNA JASA ASURANSI KENDARAAN PADA PT ASURANSI BINA DANA ARTA DENPASAR
}

\author{
Luh Novi Merta Sari ${ }^{1}$ \\ Made Mulia Handayani ${ }^{2}$ \\ ${ }^{1,2}$ Fakultas Ekonomi Universitas Ngurah Rai, Bali, Indonesia \\ 1e-mail : $\underline{\text { uhnovitamerta10@gmail.com }}$
}

\begin{abstract}
ABSTRAK
Berbagai perusahaan asuransi saat ini tidak dipungkiri bahwa terdapat persaingan yang kuat dalam menciptakan produk dan pelayanan yang berdaya saing tinggi untuk menciptakan kepuasan nasabahnya. Premi asuransi dan kualitas pelayanan merupakan variabel yang mempengaruhi kepuasan nasabah di perusahaan asuransi. Adanya perhatian dan ditemukannya permasalahan mengenai premi dan kualitas pelayanan dalam meningkatkan kepuasan nasabah asuransi kendaraan maka sangat layak dalam penelitian ini diteliti lebih jauh lagi pengaruh premi asuransi dan kualitas pelayanan terhadap kepuasan nasabah pengguna jasa asuransi kendaraan pada PT Asuransi Bina Dana Arta Denpasar. Perumusan masalah dalam penelitian ini adalah: bagaimanakah pengaruh secara simultan maupun parsial antara premi asuransi dan kualitas pelayanan terhadap kepuasan nasabah pengguna jasa asuransi kendaraan pada PT Asuransi Bina Dana Arta Denpasar? Tujuan penelitian adalah untuk mengetahui pengaruh secara simultan maupun parsial antara premi asuransi dan kualitas pelayanan terhadap kepuasan nasabah pengguna jasa asuransi kendaraan pada PT Asuransi Bina Dana Arta Denpasar. Jumlah sampel ditentukan dengan tekhnik Nonprobabily Sampling sebanyak 97 orang nasabah PT Asuransi Bina Dana Arta Denpasar. Data dianalisis dengan menggunakan uji validitas, uji reliabilitas, uji asumsi klasik, analisis regresi linier berganda, analisis determinasi, uji signifikansi simultan (F-test) dan uji signifikansi parsial ( $t$-test). Hasil penelitian menunjukkan ada pengaruh yang positif dan signifikan secara simultan maupun parsial antara premi asuransi dan kualitas pelayanan terhadap kepuasan nasabah pengguna jasa asuransi kendaraan pada PT Asuransi Bina Dana Arta Denpasar.
\end{abstract}

Kata kunci : Asuransi, Premi, Kualitas Pelayanan, Kepuasan Nasabah

\begin{abstract}
Products and services that are highly competitive to create customer satisfaction. Insurance premiums and service quality are the variables that affect customer satisfaction in insurance industries. The formulation of the problem in this study is: how is the simultaneous or partial influence between insurance premiums and service quality on customer satisfaction of users of vehicle insurance services at PT Asuransi Arta Dana Arta Denpasar? The research objective was to determine the effect of simultaneous and partial between insurance premiums and service quality on customer satisfaction of users of vehicle insurance services at PT Asuransi Bina Dana Arta Denpasar. The number of samples is determined by the Nonprobabily Sampling technique as many as 97 customers of PT Asuransi Bina Dana Arta Denpasar. Data were analyzed using validity test, reliability test, classic assumption test, multiple linear regression analysis, determination analysis, simultaneous significance test ( $F$-test) and partial significance test $(t$-test). The results showed that there were simultaneous and partial positive and significant effects between insurance premiums and service quality on customer satisfaction of vehicle insurance service users at PT Asuransi Bina Dana Arta Denpasar.
\end{abstract}

Keywords: Insurance, Premiums, Service Quality, Customer Satisfaction 


\section{PENDAHULUAN}

Kehidupan manusia modern sudah sedemikian sarat dengan berbagai ancaman dan risiko bahaya yang mengancam jiwa maupun harta kompleksnya kebutuhan manusia sehingga ingin semua kebutuhan mereka dapat tercukupi. Ancaman-ancaman bahaya tersebut menimbulkan rasa takut dan cemas pada diri manusia, sehingga inilah yang menjadi salah satu alasan pendirian perusahaan-perusahaan jasa asuransi.

Asuransi merupakan perusahaan yang dibutuhkan oleh masyarakat dalam perlindungan sewaktu-waktu, keberadaanya sudah mudah dijangkau dan sekarang sudah dimana saja. Asuransi dapat membantu secara finansial dalam tata kehidupan rumah tangga, baik dalam menghadapi risiko mendasar seperti risiko kematian, atau dalam menghadapi risiko atas harta benda yang dimiliki.

Demikian pula dunia usaha dalam menjalankan kegiatannya menghadapi berbagai risiko yang mungkin dapat mengganggu kesinambungan usahanya. Karena dipandang begitu pentingnya asuransi bagi sebagian masyarakat, maka kebutuhan akan jasa perasuransian makin dirasakan, baik oleh perorangan maupun dunia usaha di Indonesia.

Risiko yang dialami tersebut akan menimbulkan kerugian financial bagi nasabah. Bukan hanya kerugian financial yang dialami, tetapi juga rasa tanggung jawab terhadap pihak lain apabila kendaraan itu menabrak kendaraan orang lain, menabrak orang lain, atau menabrak rumah penduduk.

Terkait dengan asuransi kendaraan, terdapat 2 jenis perlindungan yang dapat diberikan oleh perusahaan asuransi, yaitu asuransi kendaraan Comprehensive atau All Risk dan asuransi kendaraan Total Loss Only (TLO). Untuk tarif premi pada kendaraan, umumnya sama dengan semua perusahaan asuransi. Hal itu dikarenakan semua perusahaan asuransi menganut pada aturan yang sudah ditetapkan oleh OJK (Otoritas Jasa Keuangan).

Salah satu perusahaan asuransi yaitu Asuransi Bina Dana Arta Tbk yang juga melakukan perluasan kegiatan usahanya dengan membuka cabang di Kota Denpasar. Berdasarkan Anggaran Dasar Perusahaan, ruang lingkup kegiatan ABDA adalah bergerak di bidang asuransi kerugian baik konvensional maupun dengan prinsip syariah. Asuransi Bina Dana Arta Tbk yang biasa dikenal dengan ABDA Insurance.

Jumlah nasabah jasa asuransi kendaraan pada PT Asuransi Bina Dana Arta Denpasar tahun 2018 dapat dilihat pada Tabel 1 sebagai berikut. 
Tabel 1

Jumlah Nasabah Jasa Asuransi Kendaraan pada PT Asuransi Bina Dana Arta Denpasar Tahun 2018

\begin{tabular}{|c|l|c|c|}
\hline No & \multicolumn{1}{|c|}{ Bulan } & Jumlah Nasabah & Perkembangan (\%) \\
\hline 1 & Januari & 200 & $(0.25)$ \\
2 & Februari & 150 & 0.57 \\
3 & Maret & 235 & $(0.32)$ \\
4 & April & 160 & 0.56 \\
5 & Mei & 250 & 0.00 \\
6 & Juni & 250 & 0.20 \\
7 & Juli & 300 & 0.10 \\
8 & Agustus & 330 & 0.05 \\
9 & September & 345 & $(0.04)$ \\
10 & Oktober & 330 & 0.21 \\
11 & November & 400 & $(0.13)$ \\
12 & Desember & 350 & $\mathbf{0 . 0 9}$ \\
\hline
\end{tabular}

Sumber: PT Asuransi Bina Dana Arta Denpasar, 2018.

Berdasarkan Tabel 1 Perkembangan jumlah nasabah jasa asuransi kendaraan pada PT Asuransi Bina Dana Arta Denpasar pada tahun 2018 memiliki rata-rata nasabah sebesar 275 nasabah atau mengalami peningkatan sebesar 0.09 persen tiap bulannya. Jumlah nasabah terbesar berjumlah 400 nasabah terjadi pada bulan November, dan jumlah nasabah terendah terjadi pada bulan Februari sejumlah 150 nasabah. Fluktuasi jumlah nasabah disebabkan adanya nasabah yang puas ataupun tidak puas pada pelayanan maupun produk jasa dari PT Asuransi Bina Dana Arta Denpasar. Kepuasan nasabah sudah menjadi keharusan bagi perusahaan yang berorientasi pada Pasar atau Konsumen.

Keberhasilan suatu perusahaan asuransi juga sangat dipengaruhi oleh bagaimana perusahaan tersebut dapat memuaskan nasabahnya, dan salah satunya dengan memberikan pelayanan kepada nasabah yang hendaknya diarahkan kepada pelayanan yang berkesinambungan.
Premi adalah sejumlah uang yang harus dibayarkan setiap bulan atau tahunnya sebagai kewajiban dari nasabah dalam keikutsertaanya di asuransi.

Pada PT Asuransi Bina Dana Arta Denpasar sebagian konsumen merasa lebih baik menunda ataupun menyudahi kebutuhan berasuransi dikarenakan biaya premi yang dianggap tidak sesuai dengan tanggungan yang didapatkan. Sebagian karyawan asuransi PT Asuransi Bina Dana Arta Denpasar dianggap kurang memberikan informasi yang detail dan sejelas-jelasnya tentang sistem perhitungan besarnya premi yang harus dibayarkan, nilai tunai selama masa pertanggungan, serta syarat-syarat umum polis. Sehingga, para nasabah merasa tidak puas dengan biaya premi yang telah dikeluarkan. Selain premi yang tidak membebani suatu nasabah, perusahaan asuransi juga harus mampu menciptakan pelayanan semaksimal mungkin. 
Memahami betapa pentingnya premi asuransi dan kualitas pelayanan bagi kepuasan pelanggan PT Asuransi Bina Dana Arta Denpasar, maka penulis tertarik untuk mengadakan penelitian dengan mengangkat judul Pengaruh Premi Asuransi dan Kualitas Pelayanan terhadap Kepuasan Nasabah Pengguna Jasa Asuransi Kendaraan pada PT Asuransi Bina Dana Arta Denpasar.

Rumusan masalah dalam penelitian ini yaitu apakah Premi Asuransi dan Kualitas Pelayanan berpengaruh secara simultan, Premi Asuransi berpengaruh secara parsial dan Kualitas Pelayanan berpengaruh secara parsial terhadap kepuasan nasabah pengguna jasa asuransi kendaraan pada PT. Asuransi Bina Dana Arta?

Adapun tujuan dari penelitian ini yaitu: untuk mengetahui apakah Premi Asuransi dan Kualitas Pelayanan berpengaruh secara simultan, pengaruh Premi Asuransi secara oparsial terhadap kepuasan nasabah pengguna jasa asuransi kendaraan pada PT. Asuransi Bina Dana Arta serta mengetahui pengaruh secara parsial terhadap pengguna jasa asuransi kendaraan pada PT Asuransi Bina Dana Arta.

Manfaat penelitian ini yaitu penelitian ini diharapkan dapat menjadi tambahan referensi ataupun pengetahuan bagi penelitian-penelitian mendatang, terutama yang berkaitan dengan pengaruh premi asuransi dan kualitas pelayanan secara simultan maupun parsial terhadap kepuasan nasabah. Hasil penelitian diharapkan dapat memberikan bahan masukan bagi pihak manajemen berkaitan dengan kebijakan pemasaran dalam meningkatkan kepuasan pada nasabah.

\section{METODE PENELITIAN}

Desain penelitian ini menggunakan metode penelitian kuantitatif. Penelitian kuantitatif adalah penelitian empiris yang datanya berbentuk angka-angka dan Metode Kuantitatif adalah metodologi penelitian yang berlandaskan pada filsafat positivisme, digunakan untuk meneliti pada populasi atau sampel tertentu dan untuk menguji hipotesis yang telah ditetapkan. Jenis penelitian yang digunakan dalam penelitian ini menggunakan jenis penelitian survey. Dalam penelitian survey, informasi yang dikumpulkan dari responden dengan menggunakan kuesioner (Sugiyono, 2012).

Lokasi penelitian ini dilaksanakan di PT Asuransi Bina Dana Arta Jl. Buluh Indah No.95, Pemecutan Kaja, Denpasar Utara, Kota Denpasar.

Obyek penelitian ini adalah premi asuransi, kualitas pelayanan dan kepuasan nasabah di PT Asuransi Bina Dana Arta Denpasar, variabel yang digunakan di dalam penelitian ini yaitu Premi Asuransi / Harga $\left(\mathrm{X}_{1}\right)$, Kualitas Pelayanan $\left(\mathrm{X}_{2}\right)$ dan Kepuasan Nasabah (Y).

Jumlah populasi dalam penelitian ini berjumalah 3.300 nasabah, yakni diambil dari penjumlahan data nasabah pada periode 2018.

Teknik pengambilan sampel dalam penelitian ini adalah teknik Nonprobably Sampling. Nonprobably Sampling adalah teknik pengambilan sampel yang tidak memberi peluang/kesempatan yang sama bagi setiap unsur atau anggota populasi untuk dipilih menjadi sampel. Sampel dalam penelitian ini adalah sebagian konsumen yang berkunjung pada Asuransi Bina Dana Arta Denpasar. berdasarkan pada 
pendekatan rumus Slovin yaitu sebagai berikut

Dari perhitungan tersebut, maka penulis mengambil menggenapkan hasil angka sampel yakni sebanyak 97 nasabah.

Sumber data yang digunakan dalam penelitian ini adalah data primer yaitu sumber data penelitian yang langsung memberikan data kepada pengumpul data, (Sugiyono, $2010: 62$ ) data primer dalam penelitian ini adalah hasil dari jawaban responden terhadap kuisioner seputar variabel yang dimaksud dan data sekunder, yaitu sumber data penelitian yang tidak langsung memberikan data kepada pengumpul data (Sugiyono, 2010 : 62), data sekunder dalam penelitian ini meliputi : buku-buku referensi, artikel, jumlah populasi dan jurnal-jurnal yang berkaitan dengan penelitian.

Adapun metode pengumpulan data yang dipergunakan dalam penelitian ini antara lain pengamatan, wawancara, kuesioner dan studi dokumentasi.

\section{Teknik Analisis Data}

Teknik analisis data dalam penelitian ini yaitu Uji Validitas (digunakan untuk melihat sejauh mana ketepatan dan kecermatan kuisioner dalam melakukan fungsinya sebagai alat ukur. Instrumen dalam penelitian ini dapat dikatakan valid apabila mampu mengukur apa yang ingin diukur dan dapat mengungkapkan data dan variabelvariabel yang diteliti secara konsisten)

Ho ditolak berarti secara parsial ada pengaruh signifikan antara Premi Asuransi dan kualitas pelayanan terhadap kepuasan nasabah menggunakan jasa asuransi pada PT Asuransi Bina Dana Arta Denpasar. dan Uji Reliabilitas Instrumen Penelitian (Uji reliabilitas yang digunakan dalam penelitian ini adalah dengan metode Alpha Cronbach. Nilai batas (cut of point) yang diterima untuk tingkat Alpha Cronbach adalah $\geq 0,60$.

\section{Uji Asumsi Klasik}

\section{Uji Normalitas}

Untuk menguji apakah data berdistribusi normal atau tidak, dapat dilakukan dengan Uji KolmogorovSmirnov, apabila sig (2-tailed) lebih besar dari $\alpha=0,05$ maka data berdistribusi normal, sedangkan apabila sig (2-tailed) lebih kecil dari $\alpha=0,05$ maka data tidak berdistribusi normal.

\section{Uji Multikolinieritas}

Jika antar variabel independen ada korelasi yang cukup tinggi (umumnya di atas 0,90), maka hal ini merupakan indikasi adanya multikolinearitas. Cara lainnya dengan melihat nilai VIF dan menggunakan jasa asuransi pada PT Asuransi Bina Dana Arta Denpasar yang dinyatakan dalam presentase

\section{Analisis Statistik Uji t (t-test)}

Analisis ini digunakan untuk mengetahui pengaruh signifikan atau tidak. Daerah Penerimaan dan Penolakan Ho dengan uji $\mathrm{t}$

Ho diterima berarti secara parsial tidak ada pengaruh signifikan antara Premi Asuransi dan kualitas pelayanan terhadap kepuasan nasabah menggunakan jasa asuransi pada PT Asuransi Bina Dana Arta Denpasar. 


\section{Analisis Statistik Uji F ( F-Test )}

Uji F (F-test) ini digunakan Untuk menguji signifikansi antara Premi Asuransi dan kualitas pelayanan secara simultan terhadap kepuasan nasabah secara serempak atau bersama-sama.

Ho diterima berarti secara simultan tidak ada pengaruh signifikan antara Premi Asuransi dan kualitas pelayanan terhadap kepuasan nasabah menggunakan jasa asuransi pada PT Asuransi Bina Dana Arta Denpasar.

Ho ditolak berarti secara simultan ada pengaruh signifikan antara Premi
Asuransi dan kualitas pelayanan terhadap kepuasan nasabah menggunakan jasa asuransi pada PT Asuransi Bina Dana Arta Denpasar.

\section{HASIL PENELITIAN}

\section{Karakteristik Responden}

Karakteristik responden digunakan untuk mengetahui keragaman dari responden yang digolongkan berdasarkan kategori jenis kelamin, umur, dan pendidikan terakhir.

Adapun karakteristik responden berdasarkan usia adalah sebagai berikut :

Tabel 2

Karakteristik Responden Menurut Usia

\begin{tabular}{|c|c|c|c|}
\hline No. & Usia (Tahun) & Jumlah & Persentase (\%) \\
\hline 1 & $16-22$ & 23 & 23,71 \\
2 & $23-29$ & 35 & 36,08 \\
3 & $30-49$ & 26 & 26,80 \\
4 & $>50$ & 13 & 13,40 \\
\hline \multicolumn{2}{|l}{ Jumlah } & $\mathbf{9 7}$ & $\mathbf{1 0 0 \%}$ \\
\hline
\end{tabular}

Sumber: Olah data SPSS 23.0 for Windows, 2019.

Berdasarkan Tabel 2 dapat diketahui bahwa kelompok responden terbanyak berada pada usia 23-29 tahun yaitu sebanyak 36,08\%. Sedangkan kelompok usia terendah berada pada kelompok umur $>50$ tahun yaitu sebanyak 13,40\%.

\section{a. Karakteristik Responden Menurut Jenis Kelamin}

Karakteristik responden berdasarkan Jenis kelamin adalah sebagai berikut :

Tabel 3

Karakteristik Responden Menurut Jenis Kelamin

\begin{tabular}{|c|l|c|c|}
\hline No. & Jenis Kelamin & Jumlah & Persentase (\%) \\
\hline 1 & Laki-laki & 62 & 63,92 \\
2 & Perempuan & 35 & 36,08 \\
\hline \multicolumn{2}{|c|}{ Jumlah } & $\mathbf{9 7}$ & $\mathbf{1 0 0 \%}$ \\
\hline
\end{tabular}

Sumber: Olah data SPSS 23.0 for Windows, 2019. 
Berdasarkan Tabel 3 dapat diketahui bahwa sebagian besar responden adalah berjenis kelamin laki-laki yaitu sebanyak $63,92 \%$ dan sisanya $36,08 \%$ adalah perempuan.

\section{b. Karakteristik Responden Menurut Pekerjaan}

Karakteristik responden berdasarkan pekerjaan dapat dilihat pada Tabel 4 sebagai berikut :

Tabel 4

Karakteristik Responden Menurut Pekerjaan

\begin{tabular}{|c|l|c|c|}
\hline No. & \multicolumn{1}{|c|}{ Pekerjaan } & Jumlah & Persentase (\%) \\
\hline 1 & Pelajar/Mahasiswa & 20 & 20,62 \\
2 & Karyawan/PNS & 31 & 31,96 \\
3 & Guru/Dosen & 10 & 10,31 \\
4 & Wiraswasta & 28 & 28,87 \\
5 & Lainnya & 8 & 8,25 \\
\hline \multicolumn{2}{|c|}{ Jumlah } & $\mathbf{9 7}$ & $\mathbf{1 0 0 \%}$ \\
\hline
\end{tabular}

Sumber: Olah data SPSS 23.0 for Windows, 2019.

Berdasarkan Tabel 4 dapat diketahui bahwa responden terbanyak berada pada kelompok pekerjaan Karyawan/PNS yaitu sebanyak 31,96\%, kelompok pekerjaan pelajar/mahasiswa sebanyak 20,62\%, kelompok pekerjaan guru/dosen sebanyak $10,31 \%$, kelompok pekerjaan wiraswasta sebanyak $28,87 \%$ dan untuk pekerjaan lainnya sebesar $8,25 \%$.

\section{Uji Validitas Instrumen}

Hasil Uji Validitas Instrumen dapat dilihat pada Tabel 5 berikut ini :

Tabel 5

Hasil Uji Validitas Instrumen

\begin{tabular}{|l|c|}
\hline Pernyataan & Koefisien Korelasi \\
\hline Premi Asuransi $\left(\mathrm{X}_{1}\right)$ & 0,886 \\
\hline X1.1 & 0,881 \\
\hline X1.2 & 0,848 \\
\hline X1.3 & 0,879 \\
\hline X1.4 \\
\hline Kualitas Pelayanan $\left(\mathrm{X}_{2}\right)$ \\
\hline X2.1 \\
\hline X2.2 & 0,892 \\
\hline X2.3 & 0,861 \\
\hline X2.4 & 0,890 \\
\hline X2.5 & 0,845 \\
\hline Kepuasan Nasabah $\left(\mathrm{X}_{3}\right)$ & 0,834 \\
\hline X2.1 & \\
\hline X2.2 & 0,932 \\
\hline X2.3 & 0,957 \\
\hline
\end{tabular}

Sumber: Data diolah, 
Berdasarkan hasil analisis pada Tabel 5, menunjukkan bahwa semua instrumen nilai koefisien korelasinya berada di atas 0,30. Hal tersebut berarti semua instrumen yang dipergunakan untuk mengumpulkan data berupa kuesioner hasilnya adalah valid.

\section{Uji Reliabilitas Instrumen}

Hasil Uji Reliabilitas Instrumen dengan Alpha Cronbach dapat dilihat pada Tabel 6 berikut ini.

Tabel 6

Hasil Uji Reliabilitas Instrumen

\begin{tabular}{|l|c|c|c|c|}
\hline \multicolumn{1}{|c|}{ Variabel } & $\begin{array}{c}\text { Jumlah } \\
\text { Instrumen }\end{array}$ & Cronbach's Alpha & Standar & Ket. \\
\hline Premi Asuransi $\left(\mathrm{X}_{1}\right)$ & 4 & 0.896 & 0,70 & Reliabel \\
\hline Kualitas Pelayanan $\left(\mathrm{X}_{2}\right)$ & 5 & 0,915 & 0,70 & Reliabel \\
\hline Kepuasan Nasabah $\left(\mathrm{X}_{3}\right)$ & 3 & 0,939 & 0,70 & Reliabel \\
\hline
\end{tabular}

Sumber : Data yang diolah, 2019.

Berdasarkan hasil analisis pada Tabel 6 didapat perhitungan masingmasing variabel nilai Cronbach's Alphanya lebih besar dari 0,70. Hal tersebut berarti semua instrumen sudah reliable dan penelitian dapat dilanjutkan.

\section{Uji Asumsi Klasik \\ a. Uji Normalitas}

Dari hasil analisis dengan menggunakan program SPSS version 22 For Windows diperoleh hasil pada Gambar 1 berikut :

Gambar 1

Uji Normalitas

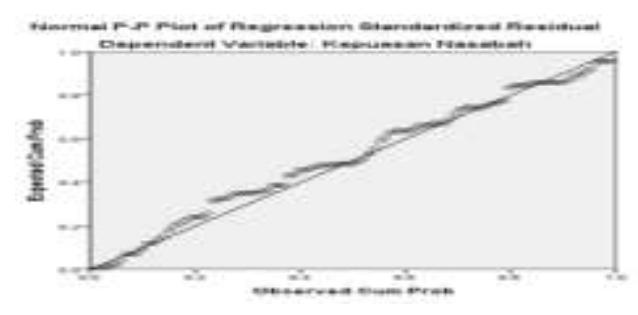

Dari Gambar 1 dapat dilihat bahwa titik - titik atau data berada didekat atau mengikuti garis diagonalnya maka dapat dikatakan bahwa nilai residual berdistribusi normal.

\section{b. Uji Multikolinearitas}

Nilai Tolerance dan VIF untuk masing-masing variabel dapat dilihat pada Tabel 7 berikut : 
Tabel 7

Uji Multikolinearitas

\begin{tabular}{|l|c|c|}
\hline Variabel Bebas & Tolerance & Nilai VIF \\
\hline Premi Asuransi $\left(\mathrm{X}_{1}\right)$ & 0,182 & 5,483 \\
\hline Kualitas Pelayanan $\left(\mathrm{X}_{2}\right)$ & 0,182 & 5,483 \\
\hline
\end{tabular}

Sumber: Data diolah.

Tabel 7 menunjukkan nilai Tolerance masing-masing variabel lebih besar dari 0,10 serta nilai VIF lebih kecil dari 10. Maka dapat disimpulkan tidak terjadi multikolinearitas antara variabel bebas dalam penelitian ini.

c. Uji Heteroskedastisitas

Gambar 2

Uji Heteroskedastisitas

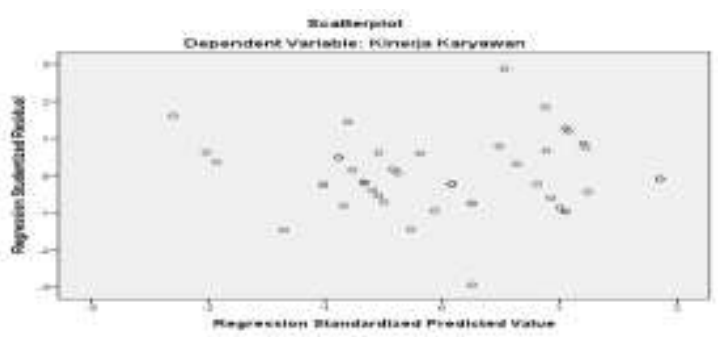

Sumber : Data yang diolah, 2019.

Dari Gambar 2 dapat dilihat bahwa titik-titik atau data menyebar diatas dan dibawah serta tidak membentuk pola tertentu dapat disimpulkan tidak ada heteroskedastisitas pada model regresi.

\section{Hasil Analisis Data}

a. Analisis Regresi Linier Berganda

Hasil analisis dapat dilihat pada Tabel 8 sebagai berikut :

Tabel 8

Hasil Analisis Regresi Linier Berganda

\begin{tabular}{|c|c|c|c|c|c|c|}
\hline \multicolumn{7}{|c|}{ Coefficients $^{\mathrm{a}}$} \\
\hline & \multirow{2}{*}{ Model } & \multicolumn{2}{|c|}{$\begin{array}{l}\text { Unstandardized } \\
\text { Coefficients }\end{array}$} & \multirow{2}{*}{$\begin{array}{c}\text { Standardized } \\
\text { Coefficients } \\
\text { Beta }\end{array}$} & \multirow[t]{2}{*}{$\mathrm{t}$} & \multirow{2}{*}{ Sig. } \\
\hline & & B & Std. Error & & & \\
\hline \multirow[t]{3}{*}{1} & (Constant) & -3.895 & .650 & & -5.996 & .000 \\
\hline & Premi Asuransi & .423 & .093 & .418 & 4.542 & .000 \\
\hline & Kualitas Pelayanan & .445 & .077 & .530 & 5.761 & .000 \\
\hline
\end{tabular}

Sumber : Data yang diolah, 2019. 
Koefisien regresi yang bertanda negatif menunjukan adanya pengaruh yang searah, dimana apabila Premi Asuransi, Kualitas Pelayanan, Distribusi Produk ditingkatkan, maka akan diikuti oleh adanya meningkatnya Kepuasan Nasabah PT Asuransi Bina Dana Arta,

\section{b. Analisis Koefisien Determinasi}

Hasil analisis dapat dilihat pada Tabel 9 sebagai berikut :

Tabel 9

Hasil Analisis Determinasi

Model Summary ${ }^{b}$

\begin{tabular}{|c|c|c|c|c|}
\hline Model & R & R Square & Adjusted R Square & Std. Error of the Estimate \\
\hline 1 & $.925^{\mathrm{a}}$ & .855 & .852 & 1.37712 \\
\hline
\end{tabular}

Sumber : Data yang diolah, 2019.

Berdasarkan Tabel 9 hasil perhitungan dengan SPSS diperoleh nilai koefisien determinasi ( $R$ Square) adalah 0,855 . Ini berarti besarnya variasi pengaruh antara Premi Asuransi dan Kualitas Pelayanan terhadap Kepuasan Nasabah adalah 85,5\% sedangkan sisanya $14,5 \%$ dipengaruhi oleh variabel lain di luar Premi Asuransi dan Kualitas Pelayanan yang tidak dibahas dalam penelitian ini.

Tabel 10

c. Uji T

Hasil Analisis Uji T

Coefficients $^{\mathrm{a}}$

\begin{tabular}{|c|l|c|c|c|c|c|}
\hline \multicolumn{2}{|c|}{ Model } & \multicolumn{2}{|c|}{ Unstandardized Coefficients } & $\begin{array}{c}\text { Standardized } \\
\text { Coefficients }\end{array}$ & \multirow{2}{*}{ Sig. } \\
\cline { 3 - 7 } \multicolumn{2}{|c|}{} & B & Std. Error & Beta & & \\
\hline \multirow{3}{*}{1} & Constant) & -3.895 & .650 & & -5.996 & .000 \\
\cline { 2 - 7 } & Premi Asuransi & .423 & .093 & .418 & 4.542 & .000 \\
\cline { 2 - 7 } & Kualitas Pelayanan & .445 & .077 & .530 & 5.761 & .000 \\
\hline
\end{tabular}

Sumber : Data yang diolah, 2019.

Hasil analisis uji t dapat dilihat pada Tabel 10 sebagai berikut :

\section{d. Uji F}

Hasil analisis uji F dapat dilihat pada Tabel 11 sebagai berikut :

Tabel 11

Hasil Analisis Uji F

ANOVA $^{\mathrm{a}}$

\begin{tabular}{|ll|r|r|r|r|r|}
\hline \multicolumn{1}{|c|}{ Model } & Sum of Squares & df & Mean Square & F & Sig. \\
\hline \multirow{3}{*}{1} & Regression & 1051.693 & 2 & 525.846 & 277.280 & $.000^{\mathrm{b}}$ \\
\cline { 2 - 7 } & Residual & 178.266 & 94 & 1.896 & & \\
\cline { 2 - 7 } & Total & 1229.959 & 96 & & & \\
\hline
\end{tabular}

Sumber: Data yang diolah, 2019. 


\section{PENUTUP}

\section{KESIMPULAN}

Berdasarkan rumusan masalah dan analisis data yang telah dilakukan serta pembahasan, maka ditarik kesimpulan dari penelitian ini adalah sebagai berikut: Premi Asuransi berpengaruh positif dan signifikan secara parsial terhadap Kepuasan Nasabah

a. Nilai t-hitung variabel Premi Asuransi adalah 4,542 lebih besar dari nilai t-tabel 1,661. Ini berarti Premi Asuransi berpengaruh positif terhadap Kepuasan Nasabah. Hal tersebut juga menunjukkan bahwa semakin baik Premi Asuransi maka Kepuasan Nasabah PT. Asuransi Bina Dana Arta Denpasar akan meningkat.

b. Kualitas Pelayanan berpengaruh positif dan signifikan secara parsial terhadap Kepuasan Nasabah

Nilai t-hitung variabel Kualitas Pelayanan adalah 5,761 lebih besar dari nilai t-tabel 1,661. Ini berarti Kualitas Pelayanan berpengaruh positif terhadap Kepuasan Nasabah. Hal tersebut juga menunjukkan bahwa semakin baik Kualitas Pelayanan maka Kepuasan Nasabah PT. Asuransi Bina Dana Arta Denpasar akan meningkat.

c. Premi Asuransi dan Kualitas Pelayanan berpengaruh secara simultan terhadap Kepuasan Nasabah

d. Berdasarkan hasil analisis didapat bahwa nilai F-hitung 277.280 lebih besar dari nilai F-tabel 3,109. Ini berarti Premi Asuransi dan Kualitas Pelayanan secara simultan berpengaruh terhadap Kepuasan Nasabah. Hal tersebut juga menunjukkan bahwa semakin baik Premi Asuransi dan Kualitas Pelayanan secara bersama-sama maka akan meningkatkan Kepuasan Nasabah PT. Asuransi Bina Dana Arta Denpasar.

\section{SARAN-SARAN}

Berdasarkan hasil penelitian dan kesimpulan yang telah dibuat maka saran-saran yang dapat diajukan berkaitan dengan penelitian ini adalah sebagai berikut :

a. Diharapkan manajemen PT. Asuransi Bina Dana Arta Denpasar dapat menawarkan premi asuransi yang menarik sehingga dapat menarik minat nasabah untuk menggunakan jasa asuransi pada PT. Asuransi Bina Dana Arta Denpasar.

b. Diharapkan manajemen PT. Asuransi Bina Dana Arta Denpasar dapat lebih meningkatkan kualitas pelayanannya kepada nasabah. Peningkatan kualitas pelayanan seperti meningkatkan keramahanan akan menambah minat nasabah .untuk menggunakan jasa asuransi pada PT. Asuransi Bina Dana Arta Denpasar. 


\section{DAFTAR PUSTAKA}

Aristyo Adisaputro. (2015) Pengaruh Premi Asuransi dan Kualitas Pelayanan Terhadap Kepuasan Nasabah Asuransi Pendidikan (Studi Kasus pada Asuransi Jiwa Bersama Bumiputera 1912 Kantor Cabang Eksekutif Semarang). Fakultas Ilmu Sosial dan Ilmu Politik Universitas Diponegoro.

Carisshya H.S. 2015. Pengaruh Kualitas Layanan Terhadap Kepuasan Nasabah PT. Prudential Life Assurance Bandung. e-Proceeding of Management $2: 1515$ - 1522

Djojosoedarso. S. (2003). Prinsip-prinsip dan Manajemen Resiko Asuransi. Jakarta. PT. Salemba Empat Satria.

Engel, BW. (1994) Perilaku Konsumen Jilid 1 Edisi Keenam. Jakarta: Bina Pura Aksara.

Fajar, L. (2008). Manajemen Pemasaran; Pendekatan Praktis. Yogyakarta: Graha Ilmu.

Herman, D. (2004). Manajemen Asuransi. Bumi Aksara. Jakarta.

Sugiyono, (2016). Metode Penelitian Kuantitatif, Kualitatif Dan Kombinasi. Alfabeta: Bandung.

Tjiptono, F. (2006). Manajemen Jasa. Andi. Yogyakarta.

Umar, Husein. (2000). Riset Pemasaran dan Perilaku Konsumen. Jakarta: PT Gramedia Pustaka Utama. 